\title{
DETERMINATION OF THE EXTRACTION CONDITIONS OF PHENOLIC COMPOUNDS FROM ARBUTUS UNEDOL. LEAVES
}

\author{
Özge Algan Cavuldak ${ }^{*}$ \\ Department of Food Engineering, Faculty of Engineering, Zonguldak Bülent Ecevit University, Zonguldak, \\ Turkey
}

Received/ Geliş: 06.04.2021; Accepted/ Kabul: 12.08.2021; Published online/ Online bask1: 13.09.2021

Algan-Cavuldak, Ö. (2021). Determination of the extraction conditions of phenolic compounds from Arbutus unedo L. leaves. GIDA (2021) 46 (5) 1218-1232 doi: 10.15237/gida.GD21065

Algan-Cavuldak, Ö. (2021). Arbutus unedo L. yapraklarından fenolik bileşiklerin ekstraksiyonunda ekstraksiyon koşullarının belirlenmesi. GID A (2021) 46 (5) 1218-1232 doi: 10.15237/gida.GD21065

\begin{abstract}
Extraction parameters in classical solvent extraction of bioactive compounds from Arbutus unedo leaves were studied using a single factor experiment approach. Effects of ethanol (EtOH) concentration (20-100\%), solvent:solid ratio $(10-90 \mathrm{ml} / \mathrm{g})$, extraction time $(20-100 \mathrm{~min})$ and extraction temperature $\left(15-70{ }^{\circ} \mathrm{C}\right)$ on total phenolic content (TPC), total flavonoid content (TFC) and total antioxidant activity (TAA) of the extracts were investigated. The optimal conditions were found as solvent concentration of $40 \% \mathrm{EtOH}$, solvent:solid ratio of 50:1, extraction time of $60 \mathrm{~min}$, and extraction temperature of $55^{\circ} \mathrm{C}$. Under these conditions, TPC, TFC and TAA were obtained as $89.58 \mathrm{mg} \mathrm{GAE} / \mathrm{g} \mathrm{dw}, 28.62 \mathrm{mg} \mathrm{CAT} / \mathrm{g} \mathrm{dw}$ and $85.25 \%$ inh, respectively. It was found that especially the flavonoid content of the extracts was highly correlated with antioxidant activity under all extraction conditions such as ethanol concentration $(\mathrm{r}=0.962)$, solvent:solid ratio $(\mathrm{r}=0.947)$, extraction time $(\mathrm{r}=0.793)$ and temperature $(\mathrm{r}=0.935)$.
\end{abstract}

Keywords: Arbutus unedo leaves, solvent extraction, polyphenols, flavonoids, antioxidant activity

\section{ARBUTUS UNEDO L. YAPRAKLARINDAN FENOLİK BİLEŞİKLERİN EKSTRAKSIYYONUNDA EKSTRAKSIYYON KOŞULLARININ BELİRLENMESİ}

\section{ÖZ}

Arbutus unedo yapraklarından biyoaktif bileşiklerin klasik çözücü ekstraksiyonundaki ekstraksiyon parametreleri tek faktörlü deney yaklaşımı kullanılarak incelenmiştir. Etanol (EtOH) konsantrasyonu (20-100 \%), çözücü:katı oranı (10-90 ml/g), ekstraksiyon süresi (20-100 dak) ve ekstraksiyon sıcaklığının $\left(15-70{ }^{\circ} \mathrm{C}\right)$ ekstraktların toplam fenolik içeriği (TPC), toplam flavonoid içeriği (TFC) ve toplam antioksidan aktivitesi (TAA) üzerindeki etkisi araştırılmış̧ır. Optimal koşullar çözücü konsantrasyonu $40 \%$ etanol, çözücü:katı oran1 50:1, ekstraksiyon süresi 60 dakika ve ekstraksiyon sıcaklığ $155^{\circ} \mathrm{C}$ olarak bulunmuştur. Bu koşullar altında TPC, TFC ve TAA değerleri sırasıyla 89.58 mg GAE/g dw, $28.62 \mathrm{mg}$ CAT / g dw ve $85.25 \%$ inh olarak elde edilmiştir. Ekstraktların özellikle flavonoid içeriğinin, etanol konsantrasyonu $(r=0.962)$, çözücü:katı oranı $(r=0.947)$, ekstraksiyon süresi $(\mathrm{r}=0.793)$ ve sıcaklık $(\mathrm{r}=0.935)$ gibi tüm ekstraksiyon koşulları altında antioksidan aktivitesi ile oldukça ilişkili olduğu bulunmuştur.

Anahtar kelimeler: Arbutus unedo yaprağı, çözücü ekstraksiyonu, polifenoller, flavonoidler, antioksidan aktivite

${ }^{*}$ Corresponding author / Yazışmalardan sorumlu yazar:
$\varangle$ : ozge.ac@beun.edu.tr
(2) (+90) 3722912602
冝: (+90) 3722574023

Özge Algan Cavuldak; ORCID no: 0000-0001-8349-9035 


\section{INTRODUCTION}

Arbutus unedo L. (also known as strawberry tree) belongs to the Ericaceae family which is an evergreen shrub or small tree native to the Mediterranean climate. It is distributed in Mediterranean region and North Africa where summers are hot and winters are rainy (Ayaz et al., 2000; Orak et al., 2011). The local distribution is shown in Mediterranean, Aegean, Marmara and Black Sea coasts of Turkey (Ayaz et al., 2000; Pabuçcuoğlu et al., 2003; Özcan and Hacıseferoğulları, 2007; Celikel et al., 2008; Orak et al., 2011; Isbilir et al., 2012; İslam and Pehlivan 2016). The name 'Kocayemiş' is commonly used for strawberry tree fruit (Arbutus unedo L.) in Turkey (Celikel et al., 2008).

The fruits and leaves of Arbutus unedo plant have importance both in local agricultural economies and in traditional medicine. The fruits are usually processed into jams, marmalades, jellies and alcoholic beverages for consumption (Alarcao-ESilva et al., 2001; Pallauf et al., 2008). They are well-known in folk medicine as antiseptics, diuretics, and laxatives. Similarly, the infusions of their leaves which are known to have diuretic, urinary antiseptic, antidiarrheal, astringent, depurative, and antihypertensive properties used in folk medicine also (Baytop, 1984; Pawlowska et al., 2006; Morgado et al., 2018). These medicinal properties are related to the high content of phenolic compounds in the fruits and leaves of $A$. unedo. There are some studies showing the phenolic profile of different parts of the plant, however, more studies have been conducted on the phenolic content of A.unedo fruits (Ayaz et al., 2000; Alarcao-E-Silva et al., 2001; Pawlowska et al., 2006; Özcan and Hacıseferoğulları, 2007; Pallauf et al., 2008; Fortalezas et al., 2010; Akay et al., 2011; İslam and Pehlivan, 2016; Albuquerque et al., 2017; López et al., 2019) compared to the studies on leaves (Pabuçcuoglu, et al., 2003; Oliveira et al., 2009; Orak et al., 2011; Malheiro et al., 2012; Erkekoglou et al., 2017). Also, the studies on phenolic and flavonoid content of both fruit and leaf of A.unedo showed that the phenolic and flavonoid content of leaf extracts was found to be higher than that of fruits' (Males et al., 2006; Mendes et al., 2011).
Plant polyphenols are a large group of secondary metabolites, which have biological properties such as antioxidant, antimicrobial, antiinflammatory, antiallergic activities. Therefore, they play a preventive role in diseases such as cancer and cardiovascular diseases (Pawlowska et al., 2006). The health-promoting properties of $A$. unedo, which were thought to be associated with polyphenols, attracted interest. Extraction method, extraction solvent and solvent concentration, solvent:solid ratio, extraction temperature, time and particle size are effective factors to obtain the extracts of phenolic compounds (Do et al., 2014; Ilaiyaraja et al., 2015; Bhebhe et al., 2016). Classical solvent extraction was used as it is the most commonly used method for extracting flavonoids (Routray and Orsat, 2012; Tzanova et al., 2020). This study aimed to see the effect of ethanol concentration, solvent:solid ratio, extraction time and extraction temperature on the extraction of phenolics from A. unedo leaves. The ranges obtained for these extraction parameters would be used in future optimization studies.

\section{MATERIAL AND METHODS Chemicals}

1,1-Diphenyl-2-picrylhydrazyl radical (DPPH'), Folin-Ciocalteu's reagent, aluminium chloride, sodium nitrite, sodium carbonate anhydrous, sodium hydroxide, gallic acid, catechin, methanol $(\mathrm{MeOH})$ and ethanol $(\mathrm{EtOH})$ were obtained from Sigma (St. Louis, MO, USA). Deionized water was used. All reagents and chemicals were analytical grade.

\section{Material}

A. unedo L. leaves were gathered in October of 2019 in Kozlu-Zonguldak (at about 105 m from above sea level) in the Western Black Sea Region, Turkey. Voucher specimens of $A$.unedo plant (No. ANK-60606) were deposited in the Science Faculty Herbarium in Ankara University, Turkey. The collected leaves were cleaned and then dried on drying papers without forming mass in shady place at room temperature for 20 days. Air-dried leaves were grounded and the ground powder were stored in glass jars at $+4{ }^{\circ} \mathrm{C}$ until extraction and analysis. 


\section{Experimental Design for Preparation of Leaf Extracts}

Classical solvent extraction was carried out with hydroalcoholic solvent system of ethanol (EtOH). $1.0 \mathrm{~g}$ of dried and ground leaf samples were weighed and mixed with the appropriate amount of $\mathrm{EtOH} / \mathrm{H}_{2} \mathrm{O}$ solvent system in glass bottles according to solvent:solid ratio. Conventional extraction was performed by stirring with a magnetic stirrer (Wisd WiseStir MSH-20A) at different temperatures and times. Single factor experiments were used for solvent extraction. The ranges for each independent variable were chosen based on the results of literature studies on the extraction of polyphenols from $A$. unedo leaves (Oliveira et al., 2009; Mendes et al., 2011; Orak et al., 2011; Malheiro et al., 2012). Then, the extract was filtered (Whatman No. 1 filter paper) and used for the determination of TPC, TFC and TAA amounts. In this study, the ranges of the parameters in the extraction of phenolic compounds from $A$. unedo leaves were statistically evaluated and aimed to be a source for future studies.

\section{Solvent $(\mathrm{E} \mathrm{OH})$ concentration}

$\mathrm{EtOH} /$ water solvent system was used as the solvent for the extraction. A. unedo leaves were extracted using various concentrations of $\mathrm{EtOH} /$ water as $20 \%, 40 \%, 60 \%, 80 \%$, and 100 $\%$. The solvent:solid ratio, extraction time and temperature were fixed at $50 \mathrm{ml} / \mathrm{g}, 60 \mathrm{~min}$ and 25 ${ }^{\circ} \mathrm{C}$, respectively.

\section{Solvent:solid ratio}

The leaves extracted at a range of solvent:solid ratio $(10,30,50,70,90 \mathrm{ml} / \mathrm{g})$ using the best $\mathrm{EtOH} /$ water concentration $(40 \%)$ determined at the first step. Extraction time and extraction temperature were fixed as $60 \mathrm{~min}$ and $25{ }^{\circ} \mathrm{C}$, respectively.

\section{Extraction time}

A. unedo leaf samples were extracted by varying the extraction time $(20,40,60,80$ and $100 \mathrm{~min})$ at fixed temperature $\left(25^{\circ} \mathrm{C}\right)$ using the best solvent concentration $(40 \%)$ and the best solvent:solid ratio $(50 \mathrm{ml} / \mathrm{g})$, which were determined at the first and second steps.

\section{Extraction temperature}

The leaf samples were extracted at different temperatures $\left(15,25,40,55\right.$, and $\left.70^{\circ} \mathrm{C}\right)$ using the best $\mathrm{EtOH} /$ water concentration (40\%), best solvent:solid ratio $(50 \mathrm{ml} / \mathrm{g})$ and best extraction time (60 min), which were determined in previous steps.

\section{Total phenolic content (TPC)}

TPC of the leaf extracts was analyzed using the modified method of Costa et al., (2009). $0.1 \mathrm{~mL}$ of ethanolic extract solution was mixed with $1 \mathrm{~mL}$ of Folin-Ciocalteu's phenol reagent and $5 \mathrm{~mL}$ of $\mathrm{Na}_{2} \mathrm{CO}_{3}$ solution. The mixture was adjusted to 10 $\mathrm{mL}$ with water. It was kept in dark for $20 \mathrm{~min}$, then the absorbance was measured at $735 \mathrm{~nm}$ using UV-VIS spectrophotometer (UV-1800, Shimadzu, Japan). The results of TPC were expressed as gallic acid equivalents (GAE) in milligrams per gram of dried weight (mg GAE/g $\mathrm{dw}$ ) using standard curve of gallic acid.

\section{Total flavonoid content (TFC)}

TFC of the leaf extracts was analyzed using the modified method of Iqbal et al., (2012). $4 \mathrm{~mL}$ deionized water, $1 \mathrm{~mL}$ extract and $0.3 \mathrm{~mL} 5 \%$ $\mathrm{NaNO}_{2}$ solution were mixed. After $5 \mathrm{~min}, 0.3 \mathrm{~mL}$ of $10 \% \mathrm{AlCl}_{3}$ was added. At the $6^{\text {th }}$ minute, $2 \mathrm{~mL}$ of $1 \mathrm{M} \mathrm{NaOH}$ and $2.4 \mathrm{~mL}$ deionized water was added and mixed. Absorbance of the mixture was measured at $510 \mathrm{~nm}$ (UV-1800, Shimadzu, Japan). The results of TFC were expressed as catechin equivalents in milligrams per gram of dried weight ( $\mathrm{mg} \mathrm{CAT} / \mathrm{g} \mathrm{dw}$ ) using standard curve of catechin.

\section{Total antioxidant activity (TAA)}

TAA of the leaf extracts was measured using a DPPH free radical scavenging assay according to the study of Lee et al., (2013). $0.5 \mathrm{~mL}$ extract was diluted 10-fold with water and mixed with $2.5 \mathrm{~mL}$ $0.12 \mathrm{mM}$ DPPH methanolic solution. After standing $30 \mathrm{~min}$ at room temperature, the absorbance was measured at $517 \mathrm{~nm}$ (UV-1800, Shimadzu, Japan). The scavenging activity of DPPH free radicals as TAA was expressed as percentage inhibition of DPPH radical and was calculated according to Equation (1):

Scavenging activity $(\%)=\left[\left(\mathrm{Abs}_{\text {control }}-\mathrm{Abs}\right.\right.$ sample) $/($ Abs control) $) \times 100$ 


\section{Statistical analysis}

All extraction experiments were replicated twice and all analyses were performed in three replications. The obtained data were expressed as the mean \pm SD (standard deviation). Significant differences $(P<0.05)$ were determined by oneway analysis of variance (ANOVA) completed by Tukey's test. Also, PCA (Pearson Correlation Analysis) was performed using Minitab (Minitab® Statistical Software 17).

\section{RESULTS AND DISCUSSION Solvent (EtOH) concentration}

Various organic solvents have been known to be use in the classical solvent extraction of phenols from various plant materials (Alothman et al., 2009; Vural et al., 2020). The most commonly used solvents for the extraction of phenolic compounds are water, $\mathrm{MeOH}, \mathrm{EtOH}$, acetone and ethylene glycol. In addition, aqueous solvents of these organic solvents have been preferred in many studies as they provide high extraction efficiency compared to pure solvents (Musa et al., 2011; Metrouh-Amir et al., 2015; Bhebhe et al., 2016; Ma et al., 2019).

Solvent selection is important for the determination of quantity and type of bioactive compounds and therefore extraction efficiency (Jovanovic-Malinovska et al., 2015). Solvent type, especially it's polarity, affects the hydrophilic and lipophilic phenolics extracted from the sample (Boeing et al., 2014). Studies on the extraction of phenolics from $A$.unedo leaves are very limited and water, $\mathrm{EtOH}$ and $\mathrm{MeOH}$ have been used as the extraction solvent in these limited studies (Pabuçcuoğlu et al., 2003; Oliveira et al., 2009; Mendes et al., 2011). In this study, $\mathrm{EtOH}$ and its aqueous mixtures $(100 \%, 80 \%, 60 \%, 40 \%, 20$ $\%$ have been preferred due to their low toxicity and no need of further processing compared to $\mathrm{MeOH}$. EtOH is also categorized as GRAS (Generally Recognized as Safe) (JovanovicMalinovska et al., 2015). In addition, it has been shown that the total phenolic and antioxidant activity results of $A$. unedo leaf extracts obtained with $\mathrm{EtOH}$ yielded higher than the others
(Pabuçcuoğlu et al., 2003, Oliveira et al., 2009). The antioxidant capacity of EtOH and $\mathrm{MeOH}$ extracts of $A$. unedo leaves were compared and Trolox equivalent antioxidant capacity (TEAC) was found as $2.25 \mathrm{mM}$ and $1.75 \mathrm{mM}$, respectively (Pabuçcuoğlu et al., 2003). Oliveira et al. (2009) studied the antioxidant activity and total phenolics of water, EtOH, $\mathrm{MeOH}$ and diethyl ether extracts of A.unedo leaves and found that the highest amount of total phenols (192.66 \pm 1.66 $\mathrm{mg}$ GAE/g extract), antioxidant activity as reducing power $\left(232.7 \mu \mathrm{g} \cdot \mathrm{ml}^{-1}\right)$ and antioxidant activity as DPPH scavenging effect $\left(\mathrm{IC}_{50}\right.$ of 63.2 $\mu \mathrm{g} \cdot \mathrm{ml}^{-1}$ ) were in EtOH extracts (Oliviera et al., 2009).

The results of the present study showed that solvent concentration significantly $\left(\begin{array}{ll}P & <0.05\end{array}\right)$ affected the analyzed variables (TPC, TFC, TAA) (Figures 1a-c). The highest value of TPC was obtained for $60 \% \mathrm{EtOH}(86.78 \mathrm{mg} \mathrm{GAE} / \mathrm{g} \mathrm{dw}$ ) whereas the lowest value was for $100 \% \mathrm{EtOH}$ (20.03 mg GAE/ g dw). 40 \% EtOH (26.53 mg $\mathrm{CAT} / \mathrm{g} \mathrm{dw}$ ) was the highest for the extraction of TFC from A. unedo leaves, which were followed by $60 \%, 80 \%, 20 \%, 100 \%$ EtOH. The lowest yield for TFC was obtained by $100 \% \mathrm{EtOH}(8.36 \mathrm{mg}$ CAT/g dw). Similar to the results of TFC, $40 \%$ EtOH concentration had also a significant effect $(P<0.05)$ on TAA of extracts giving the highest value of $82.46 \%$.

$100 \% \mathrm{EtOH}$ significantly provided the lowest value for TPC (20.03 mg GAE/g dw), TFC (8.36 $\mathrm{mg} \mathrm{CAT} / \mathrm{g} \mathrm{dw})$ and TAA $(73.40 \%$ inh) of the samples $(P<0.05)$. It was observed that when aqueous-EtOH solvent was used compared to pure solvent $(\mathrm{EtOH})$, much higher yield in phenolic extraction was obtained. Higher content of polyphenols was obtained with an increase in the polarity of the solvent used (Turkmen et al., 2006). The result was in accordance with the studies that binary solvent was suggested compared to mono-solvent (Turkmen et al., 2006; Üstündağ et al., 2016; Vural et al., 2020). 
(a)
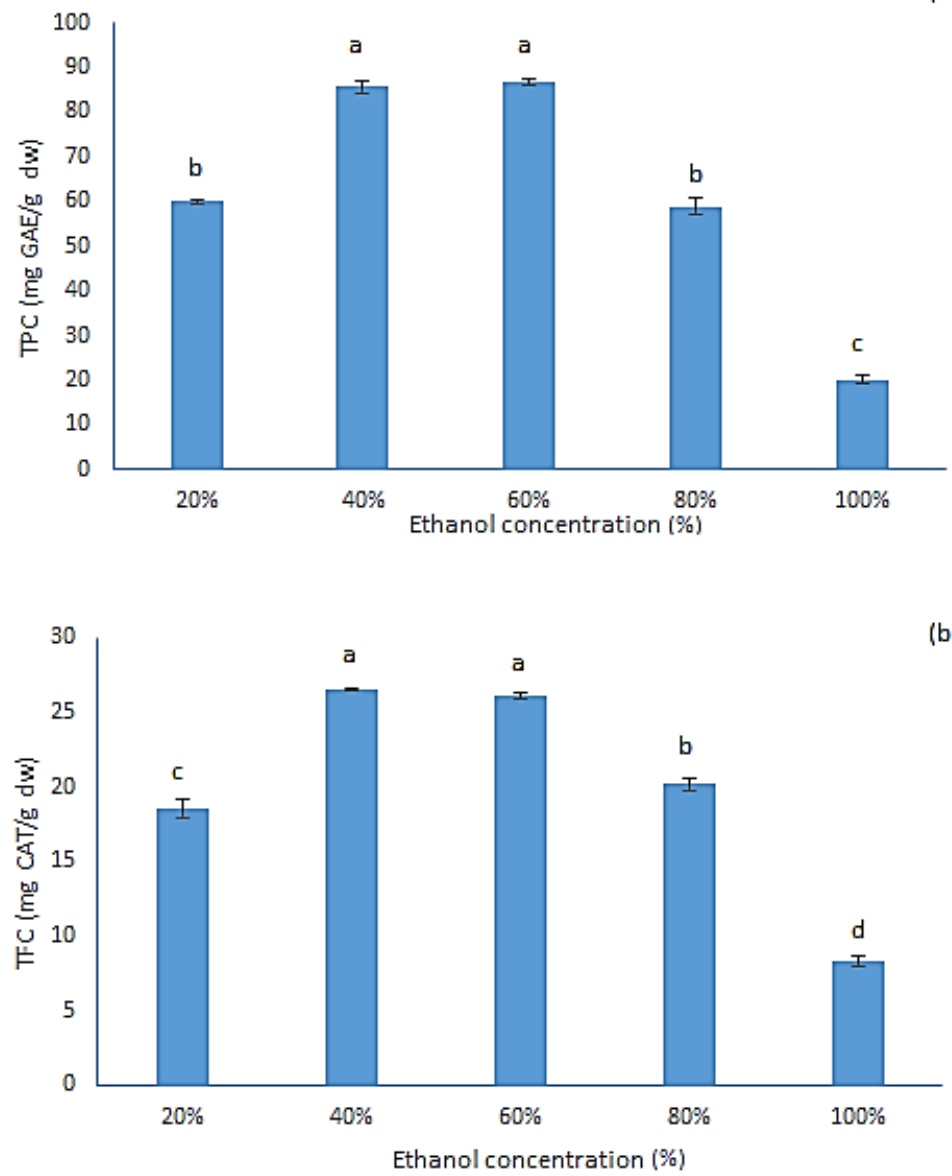

(b)

(c)

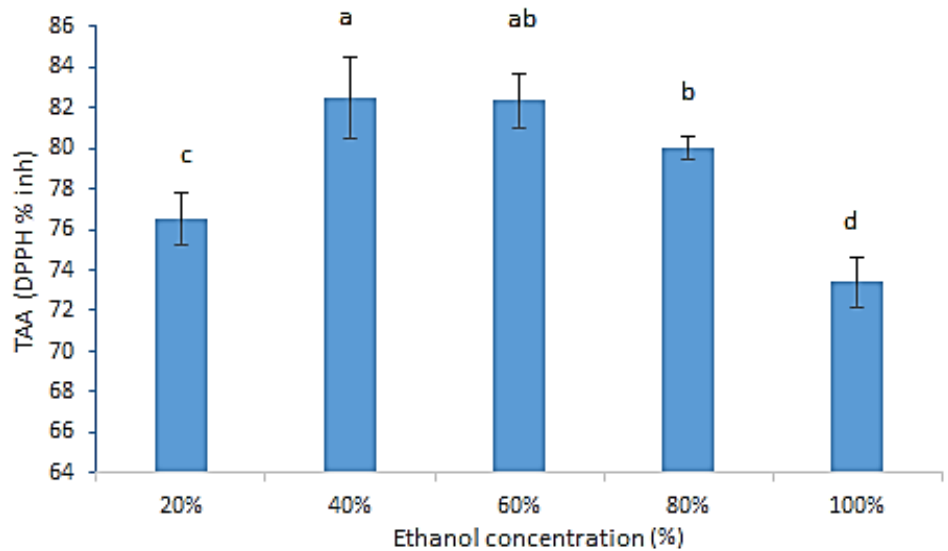

Figure 1. Effect of ethanol concentration (\%) on the extraction of TPC (a), TFC (b), TAA (c) from $A$. unedo leaves (solvent:solid ratio:50 ml/g, extraction time: $60 \mathrm{~min}$, extraction temperature: $25^{\circ} \mathrm{C}$ ) Values are mean \pm standard deviation of six measurements. The letters $(a-d)$ are significantly $(p<0.05)$ different. 
The yields of TFC and TAA were maximized at $40 \% \mathrm{EtOH}$ then followed by a decrease with further increase in concentrations of EtOH. The yield of TPC was maximized at $60 \% \mathrm{EtOH}$ however $40 \% \mathrm{EtOH}$ and $60 \% \mathrm{EtOH}$ showed no significant differences. Thus, $40 \% \mathrm{EtOH}$ was chosen as the best solvent concentration for the following steps. Solvent concentration had a significant effect on phenolic extraction and a decrease in total phenolics or antioxidant activity was observed when the solvent concentration increased above a certain value in many studies. Similarly, in the extraction of total phenolic compounds from pomegranate peel (Živković et al., 2018) and mengkudu (Morinda citrifolia) (Thoo et al., 2010), the optimum concentration was found to be $40 \% \mathrm{EtOH}$.

\section{Solvent:solid ratio}

Solvent:solid ratio is considered as an important parameter in the extraction of phenolic compounds from plants. It is generally considered that a high solvent: solid ratio provides high extraction efficiency. However, the increased cost and environmental impact due to excessive solvent consumption should also be taken into account (Pinelo et al., 2006; Dai and Mumper, 2010; Heleno et al., 2016). In this study, solvent:solid ratio was used in a wide range $(10$, $30,50,70,90 \mathrm{ml} / \mathrm{g}$ ) because it was intended to be a fundamental study to determine the ranges in phenolic extraction from $A$. unedo leaves. Different solvent: solid ratios have been observed in the studies on the extraction of phenolics from the leaves of $A$. unedo. When boiling water was used as solvent, solvent:solid ratio was $50 \mathrm{ml} / \mathrm{g}$ (Oliveira et al., 2009; Mendes et al., 2011) or 20 $\mathrm{ml} / \mathrm{g}$ (Orak et al., 2011). The solvent:solid ratio was used as $50 \mathrm{ml} / \mathrm{g}$ when the solvent was EtOH or $\mathrm{MeOH}$ (Orak et al., 2011) however it was 16.66 $\mathrm{ml} / \mathrm{g}$ when $\mathrm{EtOH}, \mathrm{MeOH}$ or diethyl ether were used (Oliveira et al., 2009).

In this study, the values of TPC, TFC and TAA were significantly affected by the parameter of solvent:solid ratio $(P<0.05)$ (Figures $2 \mathrm{a}-\mathrm{c})$. The highest value of TPC was obtained by solvent:solid ratio of $70 \mathrm{ml} / \mathrm{g}(88.66 \mathrm{mg} \mathrm{GAE} / \mathrm{g}$ $\mathrm{dw})$ and it was followed by $50 \mathrm{ml} / \mathrm{g}(85.18 \mathrm{mg}$
GAE/ g dw), $30 \mathrm{ml} / \mathrm{g}$ (71.57 mg GAE/ g dw), 90 $\mathrm{ml} / \mathrm{g}(70.25 \mathrm{mg} \mathrm{GAE} / \mathrm{g} \mathrm{dw})$ and $10 \mathrm{ml} / \mathrm{g}(50.26$ $\mathrm{mg} \mathrm{GAE} / \mathrm{g} \mathrm{dw}$ ). However, solvent:solid ratio of $50 \mathrm{ml} / \mathrm{g}$ provided the highest TFC $(26.20 \mathrm{mg}$ $\mathrm{CAT} / \mathrm{g} \mathrm{dw})$ and TAA (82.02\% inh). The lowest yield of TPC (50.26 mg GAE/ $\mathrm{g} \mathrm{dw}$ ), TFC (12.12 $\mathrm{mg} \mathrm{CAT} / \mathrm{g} \mathrm{dw}$ ) and TAA (70.92\% inh) results were obtained by solvent:solid ratio of $10 \mathrm{ml} / \mathrm{g}$. Figures $2(\mathrm{a}-\mathrm{c})$ show that the yields of TPC, TFC and TAA generally increased with increasing solvent:solid ratio however TFC and TAA results started to decrease after $50 \mathrm{ml} / \mathrm{g}$. The decrease was after $70 \mathrm{ml} / \mathrm{g}$ for TPC. Therefore, $50 \mathrm{ml} / \mathrm{g}$ was selected as solvent:solid ratio to be used in the subsequent stages to ensure both high extraction efficiency and minimal solvent consumption, thus avoiding solvent waste and extraction cost. The effect of solvent:solid ratio was significant on extraction of antioxidant compounds (TPC and TFC) and capacities (ABTS and DPPH) from $P$. niruri (Wong et al., 2013) while it was the mostly effective parameter on the extraction of TPC from dried olive leaves (Ersus Bilek, 2010).

\section{Extraction time}

Solvent extraction is a traditional extraction method and has long been used for research and industrial purposes to extract desired compounds from plant material. Despite its widespread use, generally it requires a long extraction time (Heleno et al., 2016). Long time can increase the transfer of phenolic compounds from plant to the solvent. However, extending the time may decrease the extraction efficiency by increasing the oxidation probability of phenolic compounds (Bachir Bey et al., 2014; Mokrani and Madani, 2016; Yang et al., 2017). For this reason, it is important to determine the optimum extraction time by considering the extraction efficiency, extract quality and also energy cost in solvent extraction. Extraction time was 45 minutes in solvent extraction using boling water in both studies on phenolic extraction from $A$. unedo leaves by Mendes et al. (2011) and Oiviera et al. (2009), while $\mathrm{EtOH}$ and $\mathrm{MeOH}$ extraction was performed at fixed speed during overnight (Orak et al., 2011). 
(a)
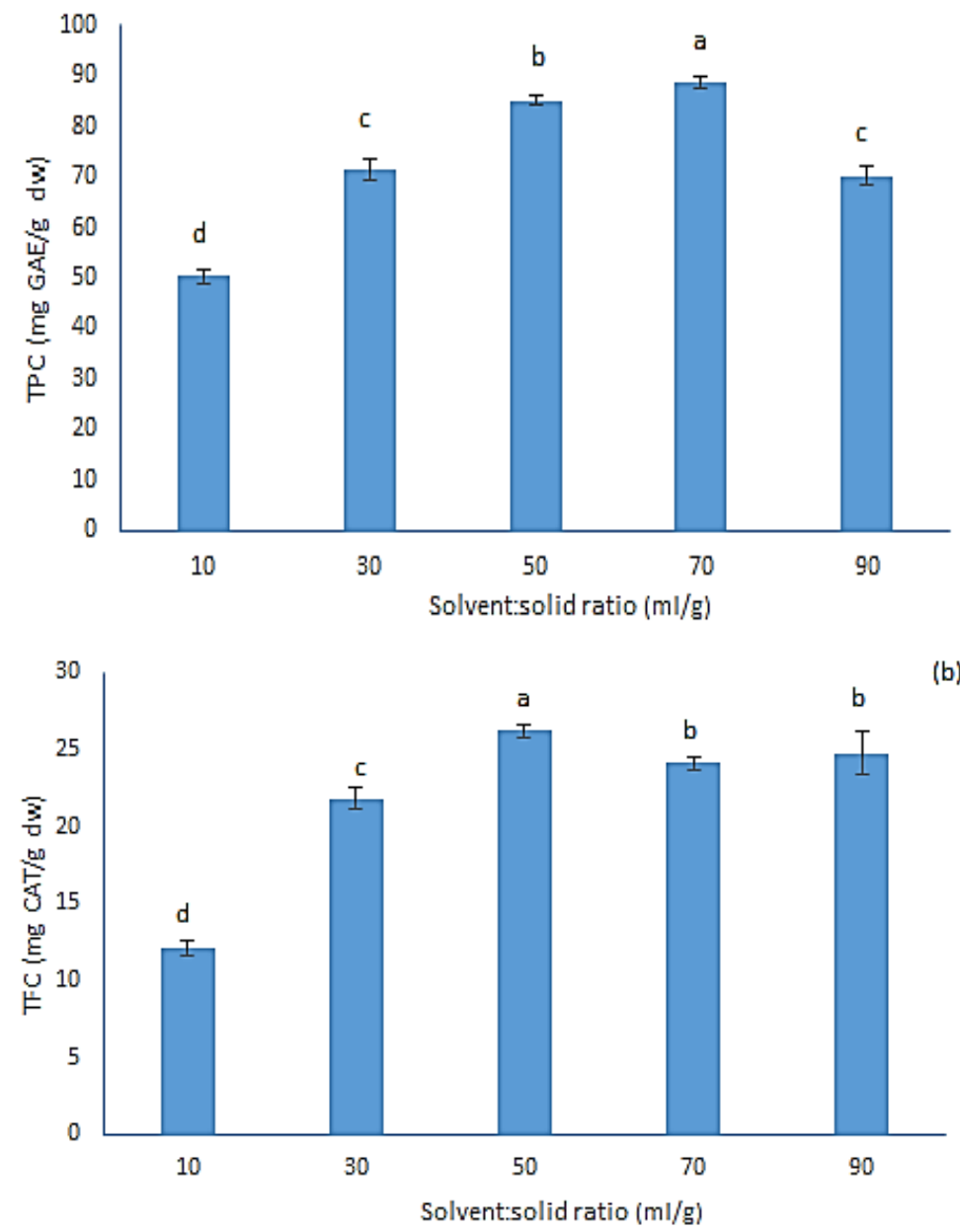

(b)

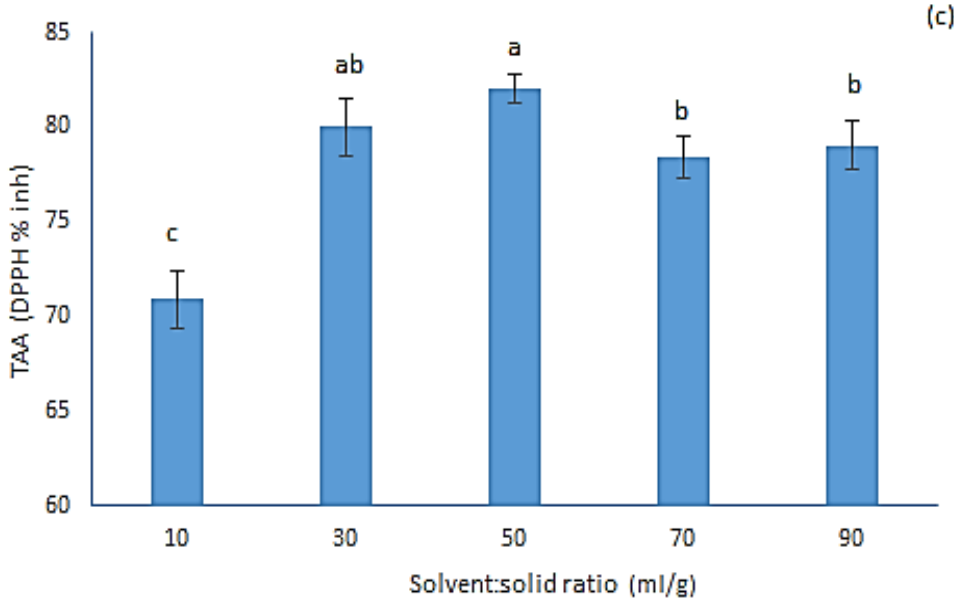

Figure 2. Effect of solvent/solid ratio on the extraction of TPC (a), TFC (b), TAA (c) from A. unedo leaves (ethanol concentration: $40 \%$, extraction time: $60 \mathrm{~min}$, extraction temperature: $25^{\circ} \mathrm{C}$ )

Values are mean \pm standard deviation of six measurements. The letters $(a-d)$ are significantly $(p<0.05)$ different. 
Figures 3a-c show the effects of extraction time on the solvent extraction of antioxidant phenolics from $A$. unedo leaves. It had siginificant effect on TPC, TFC and TAA results $(P<0.05)$. Generally TPC, TFC and TAA results increased from 20 min to 60 min (Figures $3 \mathrm{a}-\mathrm{c}$ ) however the results of TPC decreased from $20 \mathrm{~min}$ to $40 \mathrm{~min}$ and then increased from $40 \mathrm{~min}$ to $60 \mathrm{~min}$. The highest yields of TPC (85.33 $\mathrm{mg} \mathrm{GAE} / \mathrm{g} \mathrm{dw}$ ) and TAA $(82.23 \%)$ were obtained in $60 \mathrm{~min}$ of extraction time. TFC yield was highest in $100 \mathrm{~min}$ (26.78 $\mathrm{mg} \mathrm{CAT} / \mathrm{g} \mathrm{dw}$ ) and it was followed by 60 min (26.41 mg CAT/g dw). It can be seen that more flavonoids yielded in longer extraction time (100 $\mathrm{min}$ ) however there was no significant difference between the results of $60 \mathrm{~min}$ and 100 min. Additionally, the values of TPC and TAA decreased after $60 \mathrm{~min}$. Therefore extraction time of $60 \mathrm{~min}$ was chosen as optimum time. Naeem et al. (2012) preferred optimum time as $60 \mathrm{~min}$ in the extraction of phenolics from Moringa oleifera leaves (Naeem et al., 2012). Similarly, the effect of time was obtained statistically significant in the ethanolic solvent extraction of TPC from olive leaves $(P<0.05)$ (Vural et al., 2020). The results are generally in accordance with the studies in which excess extraction time reduced the yield of phenolic compounds (Liyana-Pathirana and Shahidi, 2005; Thoo et al., 2010; Mokrani and Madani, 2016).

\section{Extraction Temperature}

Extraction temperature is one of the critical parameters which effects extraction efficiency, extract quality and energy consumption due to solvent loss through evaporation (Durling et al., 2007; Ilaiyaraja et al., 2015).

Figures 4a-c show that the extraction temperatures $\left(15,25,40,55,70{ }^{\circ} \mathrm{C}\right)$ significantly affected the results of TPC, TFC and TAA $(P$ $<0.05)$. The highest results for TPC $(91.73 \mathrm{mg}$ GAE/g dw), TFC (28.62 $\mathrm{mg} \mathrm{CAT} / \mathrm{g} \mathrm{dw}$ ) and TAA $(85.25 \%)$ were obtained at $70{ }^{\circ} \mathrm{C}, 55^{\circ} \mathrm{C}$ and $55{ }^{\circ} \mathrm{C}$, respectively. Generally there was an increase in the values of TPC, TFC and TAA when the temperature increased. It was in accordance with the studies which reported that increase in heat improved the extraction efficiency of phenolic compounds and therefore antioxidant activity (Al-Farsi and Lee, 2008; Dorta et al. 2012; Mokrani and Madani, 2016). TFC and TAA results increased as the temperature increased, however, a statistically significant decrease was obtained after $55{ }^{\circ} \mathrm{C}(P$ $<0.05)$. For TPC, the increase was continued after $55{ }^{\circ} \mathrm{C}$ however, there was no significant increase from $55^{\circ} \mathrm{C}$ to $70{ }^{\circ} \mathrm{C}$. It can be related to thermal degradation of phenolic compounds at high temperatures which is one of the disadvantages of the solvent extraction (Yue et al., 2012). Thus $55^{\circ} \mathrm{C}$ of extraction temperature was chosen as the optimum temperature. Significant decreases in TFC and TAA above $55^{\circ} \mathrm{C}$ may be related to the sensitivity of phenolic compounds in $A$. unedo leaves to high temperature. Thermally stable compounds can give higher extraction yield whereas sensitive ones can degrade at high temperatures (Liyana-Pathirana and Shahidi, 2005; Thoo et al., 2010). Thus, the bioactive compounds in plant material may react differently according to their stability against heat. Time becomes important together with temperature to prevent degradation of polyphenols and to protect their radical scavenging potential due to high extraction temperature in traditional methods such as solvent extraction (Spigno et al., 2007; Yue et al., 2012). It may be recommended to keep the time short especially for sensitive phenolics even if the extraction temperature is high.

\section{Pearson Correlation Analysis}

The relationships between TPC, TFC and TAA of $A$. unedo leaf extracts under various extraction conditions were analyzed using Pearson correlation analysis. Under the parameter of EtOH concentration (Table 1), there was a positive significant correlation between TPC and TFC $(\mathrm{r}=0.995, P<0.05)$ and therefore flavonoids were found to have an important role among total phenolic compounds. This result was similar to the significant correlations between TPC and TFC found for L. aromatica (Do et al., 2014) and tropical fruits such as banana (Musa paradasiaca) and guava (Psidium guajava L.) (Alothman et al., 2009). Positive significant correlations between TAA and TPC $(\mathrm{r}=0.935, P$ 
$<0.05)$ and TAA and TFC ( $\mathrm{r}=0.962, P<0.05)$ indicate that both TPC and TFC are responsible for the antioxidant activity of the extracts. These correlations confirm that the phenolic compounds are the main compounds contributing to the antioxidant activity of $A$. unedo leaf extracts similar to some previous studies in which good correlation was observed between the antioxidant properties and TPC of the extracts
(Mello et al., 2005; Alothman et al., 2009; Oliveira et al., 2009). Since polarity of flavonoids varies, the choice of solvent with the appropriate polarity is also important. More polar solvents such as alcohol, water, acetone can be used in the extraction of more polar flavonoid glycosides (Harborne et al., 1975; Routray and Orsat 2012). This is correlated with high amount of flavonoids extracted with $\mathrm{EtOH} / \mathrm{H}_{2} \mathrm{O}$ in this study.
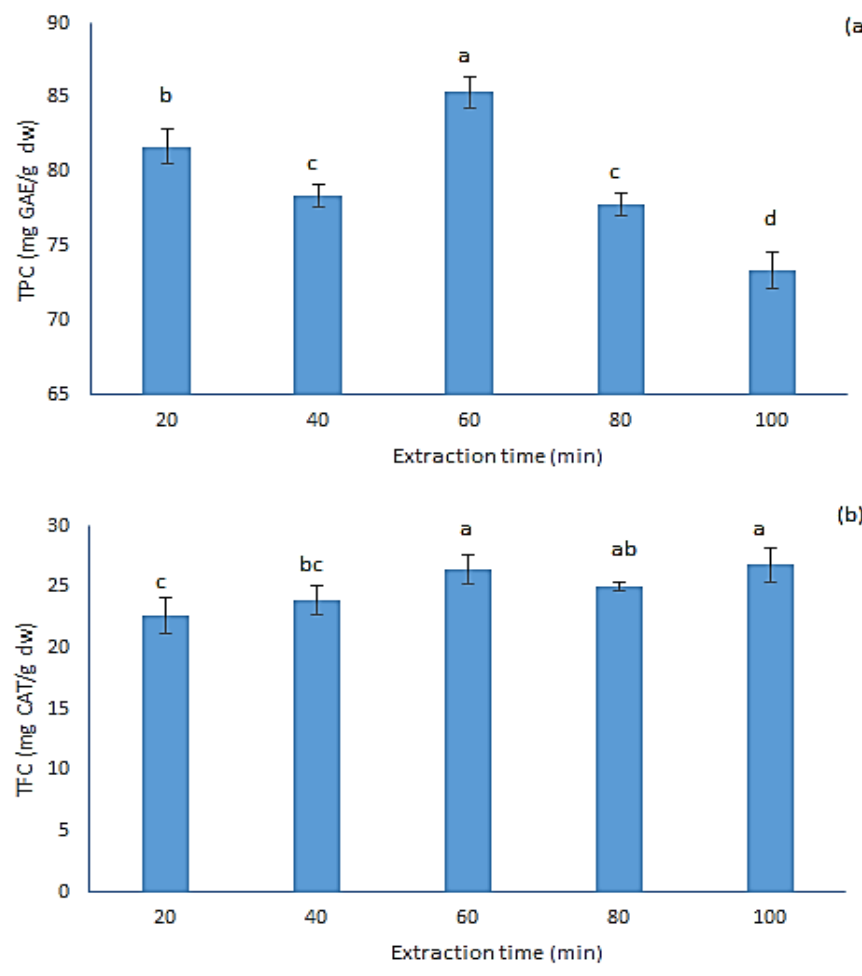

(a)

(b)

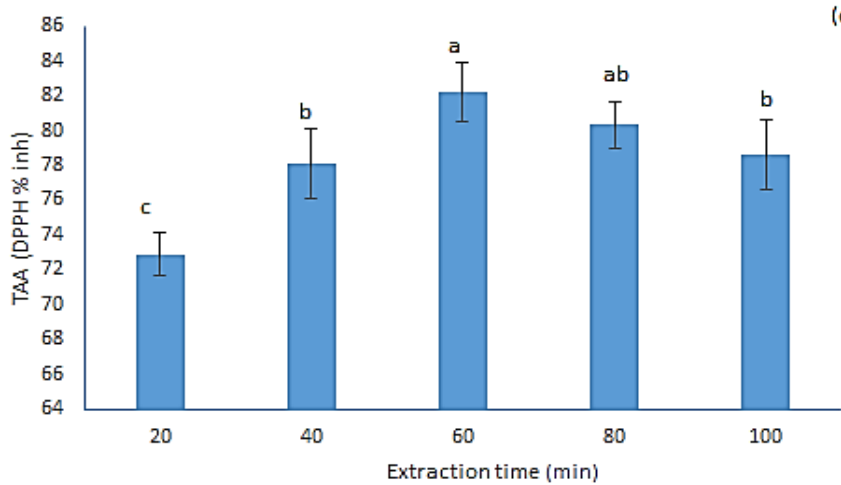

Figure 3. Effect of time on the extraction of TPC (a), TFC (b), TAA (c) from $A$. unedo leaves (ethanol concentration: $40 \%$, solvent:solid ratio: $50 \mathrm{ml} / \mathrm{g}$, extraction temperature: $25^{\circ} \mathrm{C}$ )

Values are mean \pm standard deviation of six measurements. The letters $(a-d)$ are significantly $(p<0.05)$ different. 


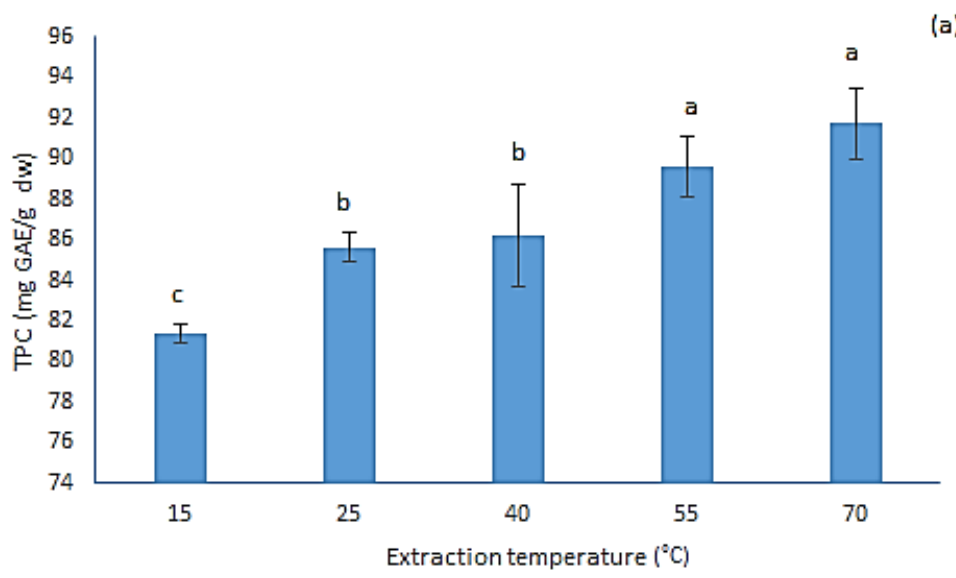

(a)
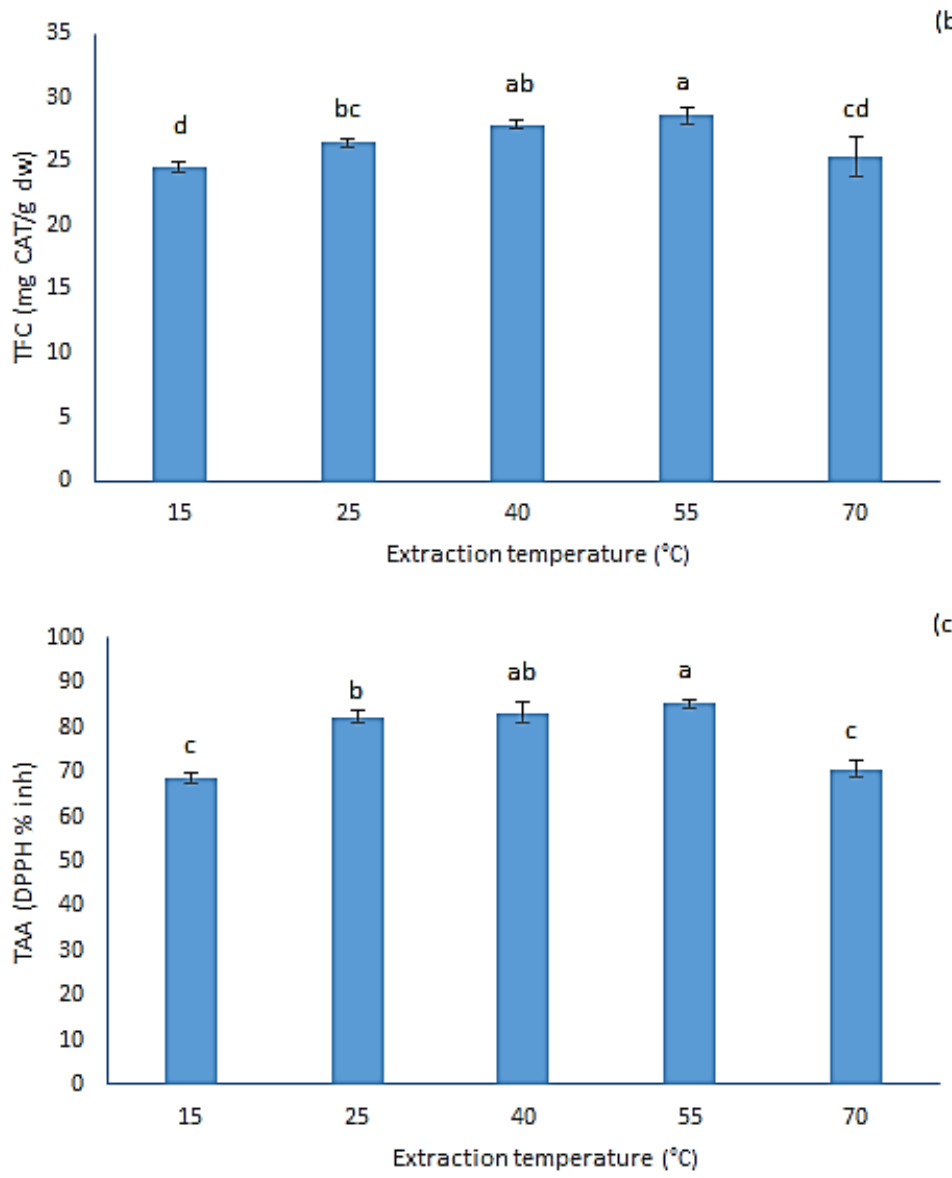

Figure 4. Effect of temperature on the extraction of TPC (a), TFC (b), TAA (c) from A. unedo leaves (ethanol concentration: $40 \%$, solvent:solid ratio: $50 \mathrm{ml} / \mathrm{g}$, extraction time: $60 \mathrm{~min}$ )

Values are mean \pm standard deviation of six measurements. The letters $(a-d)$ are significantly $(p<0.05)$ different. 
Table 1. Correlation between different assays under influence of extraction conditions

\begin{tabular}{|c|c|c|c|c|c|c|c|c|c|c|c|c|}
\hline \multirow[t]{2}{*}{$\mathrm{r}$} & \multicolumn{3}{|c|}{ Ethanol concentration } & \multicolumn{3}{|c|}{ Solvent:solid Ratio } & \multicolumn{3}{|c|}{ Time } & \multicolumn{3}{|c|}{ Temperature } \\
\hline & TPC & TFC & TAA & TPC & TFC & TAA & TPC & TFC & TAA & TPC & TFC & TAA \\
\hline TFC & $0.995^{*}$ & & & $0.882 *$ & & & -0.214 & & & 0.371 & & \\
\hline TAA & $0.935^{*}$ & $0.962^{*}$ & & 0.821 & $0.947 *$ & & 0.095 & 0.793 & & 0.216 & $0.935^{*}$ & \\
\hline
\end{tabular}

TPC, total phenolic content; TFC, total flavonoid content; TAA, DPPH radical scavenging activity

$\mathrm{r}$, Pearson correlation coefficient

* Significant level at $P<0.05$

For the solvent:solid ratio, the results were similar to those of the parameter of EtOH concentration. There was a significant positive correlation between TPC and TFC ( $\mathrm{r}=0.882, P<0.05)$. However, the correlation of TAA with TFC $(\mathrm{r}=$ $0.947, P<0.05)$ compared to TPC $(r=0.821)$ was higher and positively significant. It was observed that flavonoids have a higher and significant effect on the antioxidant activity of the sample. It can be concluded that as the solvent ratio increased, the effect of flavonoids on antioxidant activity increased.

Under the parameter of extraction time, the correlation between TFC and TPC is low and negative $(r=-0.214)$. It can be said that TFC did not contribute to TPC. In addition, only TFC was found to show a positively high but insignificant correlation with TAA $(r=0.793)$. The correlation between TPC and TAA was positive but very low $(r=0.095)$. This result was similar to the study in which the extended extraction time may cause decomposition of bioactive compounds (LiyanaPathirana and Shahidi, 2005). Overall, the extraction time negatively affected TPC, however, flavonoids were found to be more resistant to increased time than the other phenolics. These results were consistent in which that flavonoids have an important place on the antioxidant activity of the plants (Rice-Evans, et al., 1996; Mustafa et al., 2010).

Under the influence of extraction temperature (Table 1), low positive correlation between TFC and TPC $(r=0.371)$ also TAA and TPC $(r=$ $0.216)$ were found. Both have no significant difference at $P<0.05$ (Table 1). However, a strong $(\mathrm{r}=0.935)$ and significant $(P<0.05)$ correlation was found between TAA and TFC which was shown that flavonoids contributed to TAA of the extracts. It can be concluded that flavonoids in A.unedo leaf extracts are generally thermally stable while the other phenolics have low stability at high temperatures. This result was consistent with the study of Thoo et al. (2010), which stated that the TFC of $M$. citrifolia extracts are more thermally stable.

TAA of $A$. unedo leaf extracts was high and the phenolic content especially flavonoids contributed significantly to the antioxidant activity of the samples. Some studies have concluded that $A$. unedo leaves are rich in flavonoids (Males et al., 2006; Fiorentino et al., 2007). Pabuçcuoğlu et al. (2003) showed that flavonol glycosides and tannins may be active substances responsible for TAA of $A$. unedo leaves. In another study conducted on $A$. unedo leaves, the correlation between phenolic content and antioxidant activity was limited and variable, showing the complexity of the interaction of mixtures of phenols with each implicated radical (Erkekoglou et al., 2017). Different assays (DPPH, ABTS, ORAC, FRAP) have been used to measure TAA of plant materials in the literature (Capanoglu et al., 2018). It is aimed to investigate the correlation of TPC and TFC with TAA results obtained by methods other than DPPH, as well as analysis of individual flavonoids that appear to be highly effective on TAA by chromatography (HPLC) in future studies.

\section{CONCLUSION}

Single-factor experiment approach was used to obtain the optimum values of TPC, TFC and TAA of the $A$. unedo leaf extracts by investigating the extraction conditions such as solvent concentration, solvent:solid ratio, extraction time 
and extraction temperature. The highest values of TPC (89.58 mg GAE/g dw), TFC (28.62 mg CAT $/ \mathrm{g} \mathrm{dw}$ ) and TAA (85.25\% inh) of $A$. unedo leaves were obtained with $40 \% \quad \mathrm{EtOH}$ concentration, 50:1 solvent:solid ratio, $60 \mathrm{~min}$ extraction time and $55^{\circ} \mathrm{C}$ extraction temperature. The correlation between TPC, TFC and TAA of the extracts under the effect of extraction parameters were determined. Similar results were obtained under the effect of both solvent concentration and solvent:solid ratio which flavonoids have an important place in TPC and additionally both TFC and TPC contributed TAA of the extracts due to high and significant correlation coefficients. However, the results were different for under both extraction time and temperature. While the effect of flavonoids on TPC was low, the effect of these flavonoids on TAA were found to be high. It can be thought that the antioxidant flavonoids in $A$. unedo leaves were more resistant to high temperature and long time. Therefore, when determining the extraction conditions of antioxidant phenolic compounds in $A$. unedo leaves, especially the flavonoids should be considered. $A$. unedo leaves has a potential to be used in industry as a food additive or pharmaceutical due to having high antioxidant phenolics. The results of this study may provide a fundamental data for comparison of studies using new extraction methods by multi-objective optimization in the future.

\section{CONFLICT OF INTEREST}

The author declares no conflict of interest.

\section{ACKNOWLEDGEMENTS}

I would like to thank Assist. Prof. Nilüfer VURAL for her assistance in the statistical analysis section.

\section{REFERENCES}

Akay, Ş., Alpak, İ., Yesil-Celiktas, Ö. (2011). Effects of process parameters on supercritical $\mathrm{CO}_{2}$ extraction of total phenols from strawberry (Arbutus unedo L.) fruits: An optimization study.J Sep Sci, 34: 1925-1931.

Alarcao-E-Silva, M. L. C. M. M., Leitao, A. E. B., Azinheira, H. G. and Leitao, M. C. A. (2001). The Arbutus berry: Studies on its color and chemical characteristics at two mature stages. J Food Compos Anal, 14: 27-35.

Albuquerque, B.R., Prieto, M.A., Barreiro, M.F., Rodrigues, A., Curran, T.P., Barros, L., Ferreira, I.C.F.R. (2017). Catechin-based extract optimization obtained from Arbutus unedo L. fruits using maceration/microwave/ultrasound extraction techniques. Ind Crop Prod, 95: 404-415.

Al-Farsi, M.A. and Lee, C.Y. (2008). Optimization of phenolics and dietary fibre extraction from date seeds. Food Chem, 108: 977-985.

Alothman, M., Bhat, R., Karim, A.A. (2009). Antioxidant capacity and phenolic content of selected tropical fruits from Malaysia, extracted with different solvents. Food Chem, 115: 785-788.

Ayaz, F.A., Kucukislamoglu, M., Reunanen, M. (2000). Sugar, non-volatile and phenolic acids composition of strawberry tree (Arbutus unedo L. var. ellipsoidea) fruits. J Food Compos Anal, 13: 171177.

Bachir Bey, M., Meziant, L., Benchikh, Y., Louaileche, H. (2014). Deployment of response surface methodology to optimize recovery of dark fresh fig (Ficus carica L., var. Azenjar) total phenolic compounds and antioxidant activity. Food Chem, 162: $277-282$.

Baytop, T. (1984). Therapy with medicinal plants in Turkey (past and present), 1st ed.; Istanbul University, Istanbul, $305 \mathrm{p}$.

Bhebhe, M., Füller, T.N., Chipurura, B., Muchuweti, M. (2016). Efect of solvent type on total phenolic content and free radical scavenging activity of black tea and herbal infusions. Food Anal Methods, 9: 1060-1067.

Boeing, J.S., Barizão, E.O., Silva, B.C., Montanher, P.F., Almeida, V.C., Visentainer, J.V. (2014). Evaluation of solvent effect on the extraction of phenolic compounds and antioxidant capacities from the berries: application of principal component analysis. Chem Cent J, 8: 48

Capanoglu, E., Kamiloglu, S., Ozkan, G., Apak, R. (2018). Evaluation of antioxidant activity/capacity measurement methods for food products. In: Measurement of Antioxidant Activity \& 
Capacity: Recent Trends and Applications, Apak, R., Capanoglu, E., Shahidi, F. (Editor), John Wiley \& Sons Ltd., pp.273-286.

Celikel, G., Demirsoy, L., Demirsoy, H. (2008). The strawberry tree (Arbutus unedo L.) selection in Turkey. Sci Hortic, 118: 115-119.

Costa, R.M., Magalhães, A.S., Pereira, J.A., Andrade, P.B., Valentão, P., Carvalho, M., Silva, B.M. (2009). Evaluation of free radical scavenging and antihemolytic activities of quince (Cydonia oblonga) leaf: A comparative study with green tea (Camellia sinensis). Food Chem Toxicol, 47: 860-865.

Dai, J., Mumper, R.J. (2010). Plant phenolics: Extraction, analysis and their antioxidant and anticancer properties. Molecules, 15: 7313-7352.

Do, Q.D., Angkawijaya, A.E., Tran-Nguyen, P.L., Huynh, L.H., Soetaredjo, F.E., Ismadji, S., Ju, Y.H. (2014). Effect of extraction solvent on total phenol content, total flavonoid content, and antioxidant activity of Limnophila aromatica. J Food Drug Anal, 22: 296-302.

Dorta, E., Lobo, M.G., Gonzalez, M. (2012). Reutilization of mango byproducts: Study of the effect of extraction solvent and temperature on their antioxidant properties. J Food Sci, 71 (1): C80-C88.

Durling, N.E., Catchpole, O.J., Grey, J.B., Webby, R.F., Mitchella, K.A., Foo, L.Y., Perry, N.B. (2007). Extraction of phenolics and essential oil from dried sage (Salvia officinalis) using ethanolwater mixtures. Food Chem, 101: 1417-1424.

Erkekoglou, I., Nenadis, N., Samara, E., Mantzouridou, F.T. (2017). Functional teas from the leaves of Arbutus unedo: Phenolic Content, antioxidant activity, and detection of efficient radical scavengers. Plant Foods Hum Nutr, 72:176183.

Ersus Bilek, S. (2010). The effects of time, temperature, solvent:solid ratio and solvent composition on extraction of total phenolic compound from dried olive (Olea europaea L.) leaves. Gida, 35(6): 411-416.

Fiorentino, A., Castaldi, S., D’Abrosca, B., Natale, A., Carfora, A., Messere, A., Monaco, P. (2007). Polyphenols from the hydroalcoholic extract of
Arbutus unedo living in a monospecific Mediterranean woodland. Biochem Syst Ecol, 35: 809-811.

Fortalezas, S., Tavares, L., Pimpão, R., Tyagi, M., Pontes, V., Alves, P.M., McDougall, G., Stewart, D.,. Ferreira, R.B., Santos, C.N. (2010). Antioxidant properties and neuroprotective capacity of strawberry tree fruit (Arbutus unedo). Nutrients, 2: 214-229.

Harborne, J. B., Mabry, T. J., Mabry, H. (1975). The Flavonoids. London, UK: Chapman \& Hall

Heleno, S.A., Diz, P., Prieto, M.A., Barros, L., Rodrigues, A., Barreiro, M.F, Ferreira, I. C.F.R (2016). Optimization of ultrasound-assisted extraction to obtain mycosterols from Agaricus bisporus L. by response surface methodology and comparison with conventional Soxhlet extraction. Food Chem, 197: 1054-1063.

Ilaiyaraja, N., Likhith, K.R., Babu, G.R.S., Khanum, F. (2015). Optimisation of extraction of bioactive compounds from Feronia limonia (wood apple) fruit using response surface methodology (RSM). Food Chem, 173: 348-354.

Iqbal, S., Younas, U., Sirajuddin, Chan, K.W., Sarfraz, R.A., Uddin, M.K. (2012). Proximate composition and antioxidant potential of leaves from three varieties of Mulberry (Morus sp.): A comparative study. Int J Mol Sci, 13: 6651-6664.

Isbilir, S..S., Orak, H.H., Yagar, H., Ekinci, N. (2012). Determination of antioxidant activities of strawberry tree (Arbutus unedo L.) flowers and fruits at different ripening stages. Acta Sci PolHortorum Cultus, 11(3): 223-237.

İslam, A., Pehlivan, N.F. (2016). Marmara Adasinda yetişen Kocayemişlerin (Arbudus unedo L.) pomolojik özellikleri. Akademik Ziraat Dergisi, 5(1): 13-20.

Jovanovic-Malinovska, R., Kuzmanova, S., Winkelhausen, E. (2015). Application of ultrasound for enhanced extraction of prebiotic oligosaccharides from selected fruits and vegetables. Ultrason Sonochem, 22: 446-453.

Lee, L., Lee, N., Kim, Y.H., Lee, C., Hong, S.P., Jeon, Y., Kim, Y. (2013). Optimization of ultrasonic extraction of phenolic antioxidants 
from green tea using response surface methodology. Molecules, 18: 13530-13545.

Liyana-Pathirana, C., Shahidi, F. (2005). Optimization of extraction of phenolic compounds from wheat using response surface methodology. Food Chem, 93: 47-56.

López C.J., Caleja, C., Prieto, M.A., Sokovic, M., Calhelha, R.C., Barros, L. , Ferreira, I.C.F.R. (2019). Stability of a cyanidin-3-O-glucoside extract obtained from Arbutus unedo L. and incorporation into wafers for colouring purposes. Food Chem, 275: 426-438

Ma, Y., Li, X., Hou, L-X., Wei, A-Z. (2019). Extraction solvent affects the antioxidant, antimicrobial, cholinesterase and HepG2 human hepatocellular carcinoma cell inhibitory activities of Zanthoxylum bungeanum pericarps and the major chemical components. Ind Crop Prod, 142: 111872.

Males, E., Plazıbat, M., Vundac, V. B., Zuntar, I. (2006). Qualitative and quantitative analysis of flavonoids of the strawberry tree - Arbutus unedo L. (Ericaceae). Acta Pharm, 56: 245-250.

Malheiro, R., Sá, O., Pereira, E., Aguiar, C., Baptista, P., Pereira, J.A. (2012). Arbutus unedo L. leaves as source of phytochemicals with bioactive properties. Ind Crop Prod, 37: 473-478

Mello, L.D., Alves, A.A., Macedo, D.V., Kubota, L.T. (2005). Peroxidase-based biosensor as a tool for a fast evaluation of antioxidant capacity of tea. Food Chem, 92: 515-519.

Mendes, L., de Freitas, V., Baptista, P., Carvalho, M. (2011). Comparative antihemolytic and radical scavenging activities of strawberry tree (Arbutus unedo L.) leaf and fruit. Food Chem Toxicol, 49 (9): 2285-2291.

Metrouh-Amir, H., Duarte, C.M.M., Maiza, F. (2015). Solvent effect on total phenolic contents, antioxidant and antibacterial activities of Matricaria pubescens. Ind Crop Prod, 67: 249-256.

Mokrani, A., Madani, K. (2016). Effect of solvent, time and temperature on the extraction of phenolic compounds and antioxidant capacity of peach (Prunus persica L.) fruit. Sep Purif Technol, 162: 68-76.
Morgado, S., Morgado, M., Plácido, A.I., Roque, F., Duarte, A.P. (2018). Arbutus unedo L.: From traditional medicine to potential uses in modern Pharmacotherapy. J Ethnopharmacol, 225: 90-102.

Musa, K.H., Abdullah, A., Jusoh, K., Subramaniam, V. (2011). Antioxidant activity of pink-fesh guava (Psidium guajava L.): Effect of extraction techniques and solvents. Food Anal Methods, 4: 100-107.

Mustafa, R.A., Hamıd, A.A., Mohamed, S., Bakar, F.A. (2010). Total phenolic compounds, flavonoids, and radical scavenging activity of 21 selected tropical plants. J Food Sci, 75 (1): C28C35.

Naeem, S., Ali, M., Mahmood, A. (2012). Optimization of extraction conditions for the extraction of phenolic compounds from Moringa oleifera leaves. Pak J Pharm Sci, 25 (3): 535-541.

Oliveira, I., Coelho, V., Baltasar, R., Pereira, J.A., Baptista, P. (2009). Scavenging capacity of strawberry tree (Arbutus unedo L.) leaves on free radicals. Food Chem Toxicol, 47: 1507-1511.

Orak, H.H., Yagar, H., İşbilir, Ş.S., Demirci, Ş., Gümüş, T., Ekinci, N. (2011). Evaluation of antioxidant and antimicrobial potential of strawberry tree (Arbutus unedo L.) leaf. Food Sci Biotechnol, 20(5): 1249-1256.

Özcan, M.M. and Hacıseferoğulları, H. (2007). The Strawberry (Arbutus unedo L.) fruits: Chemical composition, physical properties and mineral contents. J Food Eng, 78: 1022-1028.

Pabuçcuoglu, A., Kıvçak, B:, Baş, M., Mert, T. (2003). Antioxidant activity of Arbutus unedo leaves. Fitoterapia, 74: 597-599.

Pallauf, K., Rivas-Gonzalo, J.C., del Castillo, M.D., Cano, M.P., de Pascual-Teresa, S. (2008). Characterization of the antioxidant composition of strawberry tree (Arbutus unedo L.) fruits. J Food Compos Anal, 21: 273-281.

Pawlowska, A.M., De Leo, M., Braca, A. (2006). Phenolics of Arbutus unedo L. (Ericaceae) fruits: Identification of anthocyanins and gallic acid derivatives. J. Agric. Food Chem, 54: 10234-10238. 
Pinelo, M., Arnous, A., Meyer, A.S. (2006). Upgrading of grape skins: Significance of plant cell-wall structural components and extraction techniques for phenol release. Trends Food Sci Technol, 17: 579-590.

Rice-Evans, C.A., Miller, N.J., Paganga, G. (1996). Structure-antioxidant activity relationship of flavonoids and phenolic acids. Free Radic Biol Med, 20(7): 933-956.

Routray, W., Orsat, V. (2012). Microwave-assisted extraction of flavonoids: A review. Food Bioprocess Technol, 5: 409-424.

Spigno, G., Tramelli, L., De Faveri, D.M. (2007). Effects of extraction time, temperature and solvent on concentration and antioxidant activity of grape marc phenolics. J Food Eng 81: 200-208.

Thoo, Y.Y., Ho, S.K., Liang, J.Y., Ho, C.W., Tan, C.P. (2010). Effects of binary solvent extraction system, extraction time and extraction temperature on phenolic antioxidants and antioxidant capacity from mengkudu (Morinda citrifolia). Food Chem, 120: 290-295.

Turkmen, N., Sari, F., Velioglu, Y.S. (2006). Efects of extraction solvents on concentration and antioxidant activity of black and black mate tea polyphenols determined by ferrous tartrate and Folin-Ciocalteu methods. Food Chem, 99: 835841.

Tzanova, M., Atanasov, V., Yaneva, Z., Ivanova, D., Dinev, T. (2020). Selectivity of current extraction techniques for flavonoids from plant materials. Processes, 8, 1222.
Üstündağ, Ö.G., Erşan, S., Özcan, E., Özan, G., Kayra, N., Ekinci, F.Y. (2016). Black tea processing waste as a source of antioxidant and antimicrobial phenolic compounds. Eur Food Res Technol, 242: 1523-1532.

Vural, N., Algan Cavuldak, Ö., Kenar, A., Akay, M.A. (2020). Green alcoholic solvent and UAE extraction of oleuropein from the Olea europaea L. leaves: Experimental design, optimization, and comparison with Pharmacopoeia method. Sep Sci Technol, 55 (10): 1813-1828.

Wong, B.Y., Tan, C.P., Ho, C.W (2013). Effect of solid-to-solvent ratio on phenolic content and antioxidant capacities of "Dukung Anak" (Phyllanthus niruri). Int Food Res J, 20(1): 325-330.

Yang, L., Yin, P., Fan, H., Xue, Q., Li, K., Li, X., Sun, L., Liu, Y. (2017). Response surface methodology optimization of ultrasonic-assisted extraction of Acer Truncatum leaves for maximal phenolic yield and antioxidant activity. Molecules, 22, 232.

Yue, T., Shao, D., Yuan, Y., Wang, Z., Qiang, C. (2012). Ultrasound-assisted extraction, HPLC analysis, and antioxidant activity of polyphenols from unripe apple. J Sep Sci, 35: 2138-2145.

Živković, J., Šavikin, K., Janković, T., Ćujić, N., Menković, N. (2018). Optimization of ultrasound-assisted extraction of polyphenolic compounds from pomegranate peel using response surface methodology. Sep Purif Technol, 194: 40-47. 